\title{
Public Governance and Economic Growth: Conceptual Framework
}

Maryam Hasan Al-Naser

College of Business and Finance,

Ahlia University, Manama, Bahrain.

Email: mariam_alnaser@yahoo.com

Received February, 2019; April, 2019

\begin{abstract}
This paper aims to provide a theoretical review of the relationship between public governance and economic growth and establishes future research in this field. In this paper, we discuss six principles of public governance: accountability and transparency, the rule of law, control of corruption, regulatory quality, government effectiveness, equality and inclusiveness.
\end{abstract}

Keywords: Public governance; Economic Growth; GCC countries.

Type: Research paper

This work is licensed under a Creative Commons Attribution 4.0 International License.

\section{DOI: 10.51325/ijbeg.v2i2.21}

\section{Introduction}

A society without a set of established policies is predestined to collapse, a domino effect assured to affect every fragment of the nation. According to (Maldonado, 2010), the World Banks evolving concept of good governance and its impaction human rights, briefly traces the concept of governance from the past 20 years since its emergence. Until the 1980's, governance was nothing more than a theoretical concept, following the World Bank's study in which the term good governance was introduced highlighting its necessity and significance. The first implementation of governance in 1989, reaped wholesome results as it implemented institutional reform along with an enhanced public sector in the Sub-Saharan countries delivering them from a deteriorating economy. The publication "'Governance and Development" by the World Bank in 1992 defined governance as the manner in which power is exercised in the management of a country's economic and social resources for development" (p.1). This definition introduced the world to the prominence of a governance role in the advancement of a nation. As the effects of good governance engulfed nations, the World Bank validated a definitive definition of governance: Governance is epitomized by predictable, open, and enlightened policymaking (that is, transparent processes); a bureaucracy imbued with a professional ethos; an executive arm of government accountable for its actions; and a strong civil society participating in public 
affairs; and all behaving under the rule of law. Therefore, till date these definitions reflect the innate concept of governance along with its connotation.

The term governance has attained quite a great usage in contemporary public administration. Many of the theorists in the field believe that the term governance is a systematic concept that usher administrators as administrative practices shift from the bureaucratic State which was called as the "hollow State" (Kaufmann, et al., 2009; Alareeni, 2018; Alareeni, 2019).

"Governance alludes to the sidelong and between institutional relations in organization with regards to the decline of sovereignty, the diminishing significance of jurisdictional fringes and a general institutional discontinuity". The conceptualization of the term does not, in any case, appear to have been reliable, and it has generated different definitions and implications, as demonstrated below. The United Nations Development Program (UNDP, 1997), in its 1997 approach paper characterized governance as "the activity of monetary, political and administrative authority to deal with a nation's issues at all levels. It involves the systems, procedures and institutions, through which citizens and gatherings express their interests, practice their legitimate rights, meet their commitments and intervene their disparities". In 1993, the World Bank characterized governance as the technique through which power is exercised in the administration of a nation's political, financial and social assets for development. While the World Bank has concentrated on stabilization and State changes that overwhelmingly centered on common administration conservation and privatization for a long stretch .

As indicated by Hirst, Paul (2010) "Governance alludes to managing coordination and cognizance among a wide assortment of actors with various purposes and destinations". Such on-screen characters may incorporate political performing artists and foundations, intrigue gatherings, common society, non-legislative and transnational organizations. This definition shows that while the government of a conventional State needs to adapt to inside difficulties and outside difficulties from the above on-screen characters, a portion of the capacities already the project of government might be assumed control over a portion of similar gatherings.

Munshi, Surendra (2004) offer a broader meaning of the term, they affirm that "governance can be for the most part characterized as the methods by which an action or gathering of exercises is controlled or coordinated, with the end goal that it conveys an adequate scope of results as indicated by some established standard". Canada's Institute of Governance (2002) offers another general definition, affirming that "Governance is the procedure whereby social orders or associations settles on essential choices, decide whom they include and how they render account."

As indicated by the World Bank (1993), a great governance involves sound open area administration (proficiency, viability and economy), accountability, trade and free stream of data (straightforwardness), and a legitimate structure for advancement (equity, regard for human rights and liberties). 
As per Graham, et al. (2013) great governance "signifies a participative way of administering that capacities in a capable, responsible and straightforward way in view of the standards of effectiveness, authenticity and consensus with the end goal of advancing the privileges of individual natives and the general population intrigue, therefore demonstrating the activity of political will for guaranteeing the material welfare of society and feasible improvement with social equity". A more concise meaning of good governance is offered by Plumptrewho propounds that it "implies making a powerful political structure helpful for private monetary activity: stable administrations, the rule of law, productive State organization adjusted to the parts that Governments can really perform and a solid common society autonomous of the State."

The concept of governance is not something new many people has many different views about the concept of governance but it involves the interaction between the institutions and those in the society. Many researchers have come up with many ideas as concern the idea of governance. According to world bank the concept of governance constitutes the implementation of rule of law, participation in public affairs, transparency and accountability. Han et al., (2014) stated that the concept of governance as an umbrella which defines an approach to comparative politics. To him there should be a change in the rule of games to ensure that each and every one partakes in the activities governing its nation in order to put in place a better future for the society towards productivity. According to Akpan and Effiong (2012), governance is not management but the distribution of the legitimate authority to influence and enact policies and decisions. This is the three democracy governance economic policy hierarchy of power in a nation who has the power, who in charge of the power and who is responsible to the implementation of power.

\section{Good Governance Principles}

Numerous scholars have established a good governess as a mandatory prerequisite for a nation to flourish based on the fact that since its implementation good governance has not proven otherwise. Former Secretary General of the United Nations, Kofi Annan, reflects a growing consensus when he states that "good governance is perhaps the single most important factor in eradicating poverty and promoting development". The rate of success associated with good governance allowing it to achieve favorable economic and social caliber relies directly on the adherence of a set of principles. Unlike other authoritative bodies, good governance is bounded by principle rather than rules. The definition and figure of these rules are debatable, but through evident covenant there are 6 set principles. A policy brief published in 2003 titled 'Principles for Good Governance in the 21st Century"' states that The United States Developmental Program (UNDP "Governance and Sustainable Human Development, 1997) have established a set of rules that are universally recognized.

Accountability is one of the keystones of good governance. Decision makers are accountable to the public, as well as to institutional stakeholders. Akpan and Effiong 
(2012) reported that the concept of accountability involves in 2 distinct stages: answerability and enforcement. Answerability eludes to the obligation to the government, its offices ant its agencies to provide information about their decision and activities and to legitimize to the public. Anders, G. (2010) suggests that the general society or the organization in charge of responsibility can endorse the culpable party or cure the contravening behavior. Openness and transparency ensures openness and transparency in order that stakeholders can have confidence in the decision-making and management processes, it centrally defines the processes, mediums and responsibility a legislature picks on how it impart information with its citizens. The process of openness and transparent behavior by government provides a window for citizen safely.

It is known as one of the few weapons the citizenry has to protect itself from the effective and the degenerate. Integrity guarantees clear dealing and fulfillment, in light of honesty, benevolence, objectivity and ensuring high standards of probity and appropriateness in the conduct of plan's undertakings and grumbling leadership. Integrity is crucial for the legitimacy and sustainability of democratic political framework. It relies upon positive perception by citizens of government making the wisest decision and reasonable that means acting on a responsible way and looking for general population intrigue (Bevan, et al. 1999).

The existence of the rule of law is an important principle of good governance. The principles state that all citizens public and private institutions and as well as the state are all accountable to the rule of law. Good governance ensures equality of law to everyone and total fairness in the implementation of the rule of law. Therefore, good governance ensures the protection of human rights especially to the minorities. An important principle of good governance is the implementation of effective and efficient leadership in a nation to manage the resources and revenue. Clarirepargeot said the principle of effectiveness relates to the collective skills and expertise of an organization to meet its purpose (Collier, P., 2007).

The principle of participation implies that there should be total and equal participation of the citizens both men and women in the decision- making. The effectiveness and quality of a policy of a nation depends on the involvement of all stakeholders in the decision making. Participation constitutes informing, counseling, inclusion and partnership. A definite set of principles are yet to be established considering overlapping, synonyms, contradictory and controversial conditions. The practicality of many of these principles is based on the situation at hand. Regardless of these complexities, the adherence of these principles along with proper execution is the pedestal upon which good governance is positioned. (Collier, P. and David, D., 2010) 


\section{World Wide Governance Indicators}

\subsection{Accountability and Transparency}

According to Agustin Carstens (2005), transparency ensures that information is available to measure the performance of government misuse of power and transparency helps to achieve accountability. This points out to the fact that if there is proper accountability and transparency it will lead to social instability and makes the environment not good for economic growth. Good governance is accountable for its activities and ensures transparency to avoid corruption will benefit the population. From statistics countries that practice good transparency and accountability achieve a better and good economic growth. Example is Bostwana which only source of revenue comes from the production and extraction of diamond. The government of Bostwanan has implemented proper handling and production of diamond which has attracted many investors due to the low tax rate and for the past 20 years Bostwana economy is booming and the per capita income increases to $\$ 3500$. Therefore, good governance that is transparent and is accountable wills forester the economic growth of the nation. Weaver (2010) said lack of accountability leads to greed for money and Agustin Carstens (2005) and Alareeni (2018) supported his view by adding that lack of proper transparency and accountability leads to reduction of investors and a fall of donor funding due to lack of trust and confidence.

\subsection{The Rule of Law}

The rule of law is attributed or considers being the key main player that enhances the economic growth of a nation. As a backbone of economic growth David Doyle at the oxford union on 17 July 2014 cited key points on the importance of rule of law in economic development following the ideas of professor Kenneth Dam who in 2006 said that " the protection and the enforcement of contract could contributes to the economic growth ". Good public governance ensures that laws are put in place and are available and open to the citizens in order to make clarity of the laws to each and every one this to say there should be no secrete laws. As a result, this helps to improve on the economic growth of a nation (Burgess, M., 2012).

When the rule of law is being implemented and treated equally and no given room for individual position and statues in the society it ensures stability in the nation. According to (Burgess, M. 2012), the existence of rule of law in a country will provide stability that undoubtedly encourages investment from internal and external investors to establish their businesses because the feel protected with the judiciary implementation of laws that ensures total fairness. Therefore, good public governance will enforce the economic growth due to the fact that investors, business men internal and internationally are motivated with the effective implementation of the rule of law in a given country.

Zubair and Khan (2014) as well conducted a research to explore relationship between WGI indicators and economic growth (GDP) in Pakistan. Moreover, researchers attempt 
to identify which of the WGI indicators contribute most towards economic growth. The research concluded that rule of law is an important element for development.

\subsection{Control of Corruption}

Corruption has been considered and the main leading constraints to the economic growth of many nations. Good public governance will implement good measures to control corruption to forester the economic growth of the nation. Kaufmann, (2009) indicated that corruption reduces investment and hinder the economic growth. For a good governance to improve on the economic growth of the nation has to create a possible measure were the citizens partake into the government identify priorities in the country. Therefore, Graham et al., (2013) commented that countries with better redistribution of wealth enjoy longer period of economic development, while countries that is affected with high rate of corruption suffers from poor economic and experience unfair treatment, lack of inequality. All in all, the reduction and measures of fighting against corruption leads to good governance and a better economic development.

\subsection{Regulatory Quality}

Kaufmann, et al. (2002) indicated that economic development of a state through good governance is contributed by the improvement of quality regulatory system which creates an efficient and effective incentive for both the public and private sectors. The low average citizen benefits from the good regulatory policies which help in reducing corruption which open ways for more entrepreneurship and also increase the quality of public services. Good governance keeps companies and industries alive through the subsidies provided by the state. Therefore, from the viewpoints of Ram and Zhang (2012), the provision of a regime that promotes rather than reduces economic growth in an important part of good governance. As a result, the increase in the productivity of a nation is strongly connected by the quality of good governance. Mauro (1995) supported the fact that quality of good governance has a positive effect on income. Nevertheless, the total increase and expansion of most international businesses in most countries is because of the good regulatory system which leads to higher economic growth thereby attributed to good public governance.

\subsection{Government Effectiveness}

Good governance will increase the economic growth of a nation if well implemented when the government of a nation can control its resources effectively will promote an economic growth when there is no waste of materials, mismanagement of government revenue by individual will decreases the economic growth. When there is good governance it will leads to effective and efficient growth of a nation (Xu, B., 2009; Nassar et al., 2018).

Pacific et al., (2017) examined the impact of control of corruption on economic growth of Botswana for the period of 1996-2014. The study concluded that a positive significant relationship exists between government effectiveness and GDP. 
Awan et al., (2018) examined the association among governance, corruption and economic growth in five SAARC countries: Bangladesh, India, Nepal, Pakistan and SriLanka using panel data for the period 1996-2014. Panel regression was conducted using Fixed Effects Method and the results showed that Government Effectiveness has positive and significant effect on Economic growth in selected SAARC countries.

In contrast to the result found in the previous mention studies, (Alexander, 2017) conducted a study to assess the impact of sound corporate governance on economic growth in Zimbabwe. A multiple linear regression model was used to examine the relationship. Secondary data for the period 1968 to 2015 was collected from World Bank's Worldwide Governance and World Development Indicators databases. It found that government effectiveness has negative insignificant impact on the GDP of Zimbabwe which is inconsistent with the norm. but the result might be acceptable in case of Zimbabwe as it is considering a developing country.

\subsection{Equality and Inclusiveness}

Good public governance promotes economic growth through gender equality in the nation and when there is total participation of everyone in the economic growth of the country. Good economic growth can be experience when there is no discrimination in the implementation of the rule of law, equal and fair treatment (Xu, 2009).

\section{Good Governance and Economic Growth}

In this article, the writer tried to shed light on five main issues and regarded them as the new foundations for growth in Africa based on the concept of good governance. These new foundations or elements to achieve economic development in Africa are: good governance and African development; the position of African institutions on good governance; good governance and international development assistance; good governance and public administration; good governance and economic policy reform (African Development Bank 1995).

To begin with, Green (2008) stated that there is a strong relationship between the concept of good governance and the economic development in African countries. According to an assessment by the African Development Bank (ADB) the significance of the concept for African development is relevant to the necessity to create the basic extraeconomic conditions that are essential for the growth of African economies. In this paper, the researcher identified three types or levels of governance, and micro governance, to understand the relation of good governance to growth. As stated by the writer, the issue of "good governance is so significant for African development because bad development management, institutional instabilities, and internal political shocks impede domestic and foreign investment. The second new foundation for growth in Africa is the position of African institutions on good governance. As stated by the writer, the concept of good governance was not imposed on Africa to improve the position of donors or to make aid more effective. However, he stated that the concept is implicit in most of the early documents published and the declarations passed by the (OAU, ECA, and ADB). The 
Khartoum Declaration is a prominent example that proves that the issue of good governance is a complete strategy adopted by African countries. Also, the writer stressed that since the end of the 1980s, many institutions in Africa concentrated their work and discussions on the criteria for a more developmental state which provides more services that are considered as vital requirements to the development of market forces. Most of these documents and declarations were relevant to the task of finding new methods for growth that can be achieved and maintained in Africa. The third foundation for growth in Africa, according to the researcher, is good governance in relation to international development assistance. He pointed out the importance of that foundation to understand the different positions of international donors in this regard as they have a great effect on the development process in Africa. He also observed that most of the projects and programs of the donors are primarily related to the conceptions of good governance. The fourth new foundation for development in Africa is good governance and public administration. The researcher highlighted the fact that central public administration systems were not matched by effective local systems which is regarded as a retarding factor to the development in Africa. He also made it clear that market reform policies, privatization policies, and measures to create solid economic policy could not be dealt with properly. He pointed out that good governance means that public administration reforms should become an essential part of more comprehensive governance planning and programs. The last foundation mentioned by the researcher is good governance in relation to economic policy reform. As stated by the writer, he pointed out that economic policy reform is affected by four elements: the quality of the system of public administration; the effective coordination of institutions; the mechanisms that strengthen policy credibility; revival of development planning and visions. He made it clear that these factors are the means to enhance growth in Africa. All in all, in this paper the researcher tried to argue that revival and stability of growth in Africa is now based on new foundations that became more and more relevant with the failures of its programs that are the result of overdependence on aid. These new foundations for growth in Africa are related to a governance program that emphasizes the necessity of own programming as based on African institutions and policies.

According to Smith, B. (2007), one of the econometric researchers pointed out to the fact the relationship between good governance and the economic growth is tested in the sense of "market- enhancing governance". But according to Ram and Zhang (2012), states that in order to achieve long term economic growth there should be a change in the institutional, political, economic and social reforms. However, the relationship between public governance and economic growth can be implementation and proven under effective and good accountability, effective and efficiency, equitable and inclusive, transparency and evaluation, and is important for investors to create a productive interaction between the state and the general population. The economic growth of a nation is the high rate of productivity and the increase in an economy to produce more goods and service. Moreover, economic growth of a nation is measure in terms of the gross national product or the gross domestic product. A good governance of a nation results to a strong 
economic performance and for a particular nation to effectively achieve its economic growth the government has to look in the factors which can either reduce the economic growth or increases the economic growth of a county.

Since the denouement of the 1980s the issue of good governance is ruling the world wide discussion about improvement and global help to Africa. Most essential, the talk is as yet going on. Presently, it makes a difference how to enhance the African governance systems, and what the international community can do to advance good governance, in this manner enhancing the general improvement conditions in Africa (Akpan and Effiong, 2012).

While there is a huge agreement in the writing on the negative effect of corruption on economic development, Karl keeps on arguing that the impact of corruption on development is setting particular and related with components, for example, the country's legal and institutional framework, quality of governance and political regime. He presumes that in some highly regulated states of Africa do not have effective government institutions and governance systems, corruption can compensate for red tape and institutional weaknesses and "grease the wheels" of the economy. Not only does corruption influence economic improvement as far as economic productivity and development, it additionally influences equitable distribution of resources across the population, increasing income inequalities, undermining the effectiveness of social welfare programs and ultimately resulting in lower levels of human development. This, thus, may undermine long-term sustainable development, economic development, and equality (Barratt, 1989).

Court et al., (2012) reported that regardless of more than forty years of political autonomy, Africa's goal and expectations remain today generally unfulfilled. The administration question has turned into a repeating issue in the talk on the African projects. Smith (2007) Pointed out that the governing class has been target of humiliate, criticism, condemnation and disdain in view of the pervasive and persistent socio economic and political crisis. He stated further that the economic domain has been characterized by huge external debt overhang, net capital flight, disinvestments, collapse of social infrastructure, food crisis and insecurity, over-devalued national currency, pervasive poverty, unpopular, repressive and alienating economic policies. The idea of "Governance" then again isn't new. It has been around in both political and scholarly talk for quite a while, alluding in a nonexclusive sense to the assignment of running an administration or some other proper element, for instance, a country. More recently, it has gained particular importance in the literature on Africa development as a result, among other things, of the World Bank (1989) distinguishing the crisis on the continent as one of governance. In particular, the Bank refers to such phenomena as the extensive personalization of power, the adjuration of fundamental human rights, widespread of corruption, and the pervasiveness of unelected and unaccountable government (El-Halaby et al., 2018). 
Green, W. H (2008) states that the imperative political and economic agenda (IPEA) for Africa of 1994 emphasizing not only political changes but also economic and social changes at national and regional levels. In political; Agenda, good governance is related to more than democracy, respecting human rights, and suppression of corruption. Economic Agenda focuses on a conversion of economic structures, a more dynamic role for export sectors and the necessity of newly designed reconciliation programs. The basic presumption of IPEA is that Africa is today and remains in future very much on its own and therefore has to start a new regional program for Africa and on its own capacities and resources.

\section{Performance in the World Governance Indicators}

Good governance is an alarming topic in discussions presently, irrespective of which the inherent need for good governance is universal (Greene, 2015). Two important advancements clarify the rising worry over governance and its role in advancement since the late 1980s. One is the development of new stream of financial matters known as the new institutional economics. These stresses unoriginal and fair establishments for security property, rights and contracts, which empower the augmentation of market, exchange, investment and innovation. The second advancement is expanding worry that the effectiveness of development assistance depends not just on the idea of the approaches sought after, yet in addition on the nature of government. WGI is a forum in which the variables used are mostly collected from the World Bank. The indicators are mainly building on 30 opinions and perception-based surveys of numerous governance measures from investment consulting firms, non-governmental organizations, think tanks etc.

There are six WGI indicators categorized under three criteria focused on evaluating the outcome of the procedures of governance. The first of the three criteria is the process by which governments are selected, monitored and replaced. Voice and Accountability (VA) is one of the two indicators responsible for the first criteria, it is defined as "capturing perceptions of the extent to which a country's citizens are able to participate in selecting their government, as well as freedom of expression, freedom of association, and a free media.". Political Stability and Absence of Violence (PV) is the next indicator that is measured by the possibility of any illegal means or terrorism disrupting the government (Kagundu, 2016).

The criteria measure the capacity of the government to effectively formulate and implement sound policies. This is measured by two indicators, government effectiveness and regulatory quality. Government Effectiveness (GE) is defined as "capturing perceptions of the quality of public services, the quality of the civil service and the degree of its independence from political pressures, the quality of policy formulation and implementation, and the credibility of the government's commitment to such policies". Regulatory Quality (RQ) involves capturing the capability of the government with regards to improving public and private sectors through rigorous policies and regulations. The final criteria involve the respect of citizens and the state for the institutions that govern 
economic and social interactions among them. Rule of Law is the indicator which capturers the awareness and acceptance of rules and regulations of the society, law enforcement and its affiliated members (Kaufmann et al., 2002). Control of Corruption is the last of the six indicators and has received a universal definition as a measurement of "the extent, to which public power is exercised for private gain, including both petty and grand forms of corruption, as well as "capture" of the state by elites and private interests" (Mauro, 2005; Linda et al., 2018).

\section{Conclusion}

To conclude the highlighted indicators above remains so difficult to be measure the quality of life but in as much the worldwide indicators such as control of corruption, political stability, accountability and transparency have greatly played a great rule in the promotion and implementation of good governance and increases the economic growth of many countries. In 2005 -2012 the database of an international organization was assessed mostly using data analysis.

The results of this analysis where positive related to the human development index (HDI) and the government. There was a negative relationship between the GDP and the control of corruption. Therefore, corruption as well as some of the indicators have been criticized by some scholars due to the fact that corruption cannot be measure in as much that the economic growth of some countries are growing some are not base on the low level of corruption control. The worldwide governance indicators are to imprecise to give a clear comparison of governance over time or across nations. Despite the criticisms of this indicators they have change and improve on the economic growth of many nations the participation of minorities in the implementation of the rule of law and the political stability of some nations have attracted many investors and forester the economic growth.

\section{References:}

ADB (African Development Bank) 1995 report, Abidjan

Afolabi, J. O. (2019). The impact of governance on economic development in West Africa: A system GMM dynamic panel approach. Acta Universitatis Danubius. Economica, 15(3).

Akpan, G. E., \& Effiong, E. L. (2012). Governance and development performance: a cross-country analysis of Sub-Saharan Africa. Journal of Economics and Sustainable Development, 3(14), 54-65.

Alareeni, B. (2018). The impact of firm-specific characteristics on earnings management: evidence from GCC countries. International Journal of Managerial and Financial Accounting, 10(2), 85-104. https://doi.org/10.1504/IJMFA.2018.10012808

Alareeni, B. (2018). Does corporate governance influence earnings management in listed companies in Bahrain Bourse?. Journal of Asia Business Studies, 12(4), 551570. https://doi.org/10.1108/JABS-06-2017-0082

Alareeni, B.A. (2019). The associations between audit firm attributes and audit qualityspecific indicators: A meta-analysis, Managerial Auditing Journal, 34(1), 6-43. https://doi.org/10.1108/MAJ-05-2017-1559 
Alasfoor, R. (2007). The Gulf Cooperation Council: its nature and achievements (Doctoral dissertation, Lund University).

Alqallaf, H. and Alareeni, B. (2018). Evolving of selected integrated reporting capitals among listed Bahraini Banks. International Journal of Business Ethics and Governance, 1(1), 15-36. https://doi.org/10.51325/ijbeg.v1i1.10

Anders, G. (2009). In the shadow of good governance: an ethnography of civil service reform in Africa. Brill. https://doi.org/10.1163/ej.9789004179820.i-168

Anderson, B. B. (2015). Corrupting activities and economic development. World Journal of Entrepreneurship. Management and Sustainable Development, 11(1), 64-70. https://doi.org/10.1108/WJEMSD-07-2014-0020

Awan, R. U., Akhtar, T., Rahim, S., Sher, F., \& Cheema, A. R. (2018). Governance, corruption and economic growth: A panel data analysis of selected SAARC countries. Pakistan Economic and Social Review, 56(1), 1-20.

Barratt N (1989). The co-operative model as an instrument in the community economic development process. Institute of Social and Economic Research, Working Paper No. 41, Rhodes University, Grahamstown

Bauer, P. T. (1972). Equality, the Third World and Economic Delusion (London: Weidenfeld and Nicolson, 1981), chap. 5. See also PT Bauer, Dissent on Development.

Beleiu, I., Pop, Z. C., \& Țâmpu, D. L. (2015). Effects of good governance on economic development-Case study on Romania. Review of Economic Studies and Research Virgil Madgearu, 8(1), 5-23.

Bevan, D., Collier, P., \& Gunning, J. W. (1999). The political economy of poverty, equity and growth: Nigeria and Indonesia. The political economy of poverty, equity and growth: Nigeria and Indonesia.

Brzáková, K., \& Kraft, J. (2017). Economic context of european subsidies and their impact on regional economic disparities on the example of the czech republic. Economics and Management. https://doi.org/10.15240/tul/001/2017-2-005

Burgess, M. (2012). Dangers of environmental extremism, analysis of debate over India's Social Forestry Programme, Economic and Political Weekly, 27(40), 1-12.

Collier, P., \& Dollar, D. (2002). Aid allocation and poverty reduction. European economic review, 46(8), 1475-1500. https://doi.org/10.1016/S0014-2921(01)00187-8

Court, J., Hyden, G. and Mease, K. (2012). Governance Performance: The Aggregate, World Governance Survey Discussion Paper No. 3, United Nations University.

Denzin, N., \& Lincoln, Y. (Eds). (2010). Handbook of Qualitative Research. Thousand Oaks, CA: Sage.

Dullah, M., Asid, R., Kogid, M., \& Lily, J. (2011). Economic growth and population growth: Empirical testing using Malaysian data. Interdisciplinary Journal of Research in Business, 1(15), 17-24.

El-Halaby, S., Alzunaydi, M. and El-Ghazaly, M. (2018). The Determinants of capital structure and dividend policy: empirical evidence from the Kingdom of Saudi Arabia Market, International Journal of Business Ethics and Governance, 1(2), 4571. https://doi.org/10.51325/ijbeg.v1i2.16

Ganguli, S. (2016). An economic analysis of sustainability of a potential GCC economic and monetary union during 2005-2014. World Journal of Entrepreneurship, Management and Sustainable Development; Brighton 12(3), 194-206. https://doi.org/10.1108/WJEMSD-01-2016-0005 
Graham, J. Amos, B. \& Plumptre T. (2013). Principles for Good Governance in the 21st Century Policy Brief No. 15, Institute on Governance, Retrieved from www.iog.ca/publications/policy briefs.

Green, W. H. (2008). Econometrics analysis, 5th ED., Upper Saddle River, New Jersey.

Greene, W. H. (2015). Reconsidering heterogeneity in panel data estimators of the Stochastic Frontier Model, Journal of Econometrics, 126(2), 269-303. https://doi.org/10.1016/j.jeconom.2004.05.003

Han, X., Khan, H. A., \& Zhuang, J. (2014). Do governance indicators explain development performance? A cross-country analysis. A Cross-Country Analysis (November 2014). Asian Development Bank Economics Working Paper Series, (417). https://doi.org/10.2139/ssrn.2558894

Hatem Mahran (2007). Inflation in the GCC countries and the role of oil funds in economic stability.

Hirst, Paul. (2000). Democracy and Governance in Pierre, Jon (ed.), Debating Governance: Authority, Steering, and Democracy, Oxford University Press. https://dspace.tul.cz/handle/15240/20842Date: 2017-06-15

Kaufmann, D. Kraay, A. \&Mastruzz, M. (2010). The Worldwide Governance Indicators: Methodology and Analytical Issues, World Bank Policy Research Working Paper. Washington, D.C.

Kaufmann, D., Kraay, A., \& Mastruzzi, M. (2009). Governance matters VIII: Aggregate and individual governance indicators 1996-2008. The World Bank. https://doi.org/10.1596/1813-9450-4978

Kaufmann, D., Kraay, A., \& Mastruzzi, M. (2010). The Worldwide Governance Indicators: Methodology and Analytical Issues (World Bank Policy Research Working Paper No. 5430). Washington, DC: The World Bank.

Kaufmann, Daniel in Kraay, Aart (2002). Growth without Governance /draft paper/, The World Bank, May https://doi.org/10.1353/eco.2002.0016.

Kruja, A. (2013). Sustainable economic development, a necessity of the $21 \mathrm{st}$ century. Mediterranean Journal of Social Sciences, 4(10), 93. https://doi.org/10.5901/mjss.2013.v4n10p93

Linda, F., Rym, T., \& Mounir, K. (2018). The Impact of governance on the level of disclosure and its role in attracting and supporting foreign investment: model of Qatar Stock Exchange. International Journal of Business Ethics and Governance, 1(1), 37-63. https://doi.org/10.51325/ijbeg.v1i1.11

Maki, P. L., (2004). Assessing for learning: building a sustainable commitment across the institution Sterling, VA: Stylus.

Maldonado, N. (2010). The World Bank's evolving concept of good governance and its impact on human rights. In Doctoral Workshop on Development and International Organizations. Stockholm, Sweden, May (29-30).

Malkawi, B. H. (2011). Legal architecture and design for Gulf Cooperation Council economic integration. Journal for Juridical Science, 36(2), 58-96.

Maune, A. (2017). The strong influence of sound corporate governance on economic Growth: evidence from Zimbabwe. Problems and Perspectives in Management, 15 (2 (c. 2)), 445-455. https://doi.org/10.21511/ppm.15(2-2).2017.13

Mauro, P. (1995). Corruption and growth, quarterly journal of economics, 110, 681-712. https://doi.org/10.2307/2946696

Munshi, Surendra. (2004). Concern for Good Governance in Comparative Perspective, in Munshi, Surendra and Biju Paul Abraham (eds.), Good Governance, Democratic 
Societies and Globalization, New Delhi, Sage Publications. https://doi.org/10.4135/9788132104063

Nassar, S. (2018). The Impact of intellectual capital on corporate performance of IT companies: Evidence from Bursa Istanbul, International Journal of Business Ethics and Governance, 1(3), 1-10. https://doi.org/10.51325/ijbeg.v1i3.17

Opoku, D. K. (2009). The bottom billion: why the poorest countries are failing and what can be done about it. Paul collier. Africa today, 55(4), 134-136. https://doi.org/10.2979/AFT.2009.55.4.134

Pacific, Y. K. T., Ramadhan, A. A., \& Gabriella, N. M. A. (2017). Does Control of Corruption, Accelerate Economic Growth in Botswana?. Global Journal of HumanSocial Science Research, 17(6), 41-50.

Ram, R. and H. Zhang. (2012). Foreign Direct investment and economic growth: evidence from cross-country data for the 1990s. Economic Development and Cultural Change, 51, 205-215. https://doi.org/10.1086/345453

Smith, B. (2007). Good Governance and Development. New York, NY: Palgrave Macmillan. https://doi.org/10.1007/978-1-137-06218-5

United Nations Conference on Trade and Development (UNCTD) (2009). World Investment Report 2009. New York, NY: United Nations Publications. Retrieved 03-23-2010 from http://unctad.org/en/docs/wir2009_en.pdf

United Nations Development Programme, Governance for sustainable human development, UNDP policy document, New York, 1997.

World Bank, Governance, Washington, D.C., 1993.

Xu, B. (2009). Multinational Enterprises, Technology Diffusion, and Host Country Productivity Growth.

Yongjin SA. (2011). Government size, economic growth and unemployment: evidence from advanced and developing economy countries (a time series analysis, 19962006). International Review of Public Administration, 16(2), 1-20. https://doi.org/10.1080/12264431.2011.10805198

Zubair, S. S., \& Khan, M. (2014). Good governance: Pakistan's economic growth and worldwide governance indicators. Pakistan Journal of Commerce and Social Sciences, 8(1), 258-271. 